IZA DP No. 5574

Union Threat and Non-Union Employment:

A Natural Experiment on the Use of Temporary Employment in British Firms

Andrea Salvatori

March 2011 


\title{
Union Threat and Non-Union Employment: A Natural Experiment on the Use of Temporary Employment in British Firms
}

\author{
Andrea Salvatori \\ ISER, University of Essex \\ and IZA
}

\author{
Discussion Paper No. 5574 \\ March 2011
}

\author{
IZA \\ P.O. Box 7240 \\ 53072 Bonn \\ Germany \\ Phone: +49-228-3894-0 \\ Fax: +49-228-3894-180 \\ E-mail: iza@iza.org
}

Any opinions expressed here are those of the author(s) and not those of IZA. Research published in this series may include views on policy, but the institute itself takes no institutional policy positions.

The Institute for the Study of Labor (IZA) in Bonn is a local and virtual international research center and a place of communication between science, politics and business. IZA is an independent nonprofit organization supported by Deutsche Post Foundation. The center is associated with the University of Bonn and offers a stimulating research environment through its international network, workshops and conferences, data service, project support, research visits and doctoral program. IZA engages in (i) original and internationally competitive research in all fields of labor economics, (ii) development of policy concepts, and (iii) dissemination of research results and concepts to the interested public.

IZA Discussion Papers often represent preliminary work and are circulated to encourage discussion. Citation of such a paper should account for its provisional character. A revised version may be available directly from the author. 


\section{ABSTRACT \\ Union Threat and Non-Union Employment: A Natural Experiment on the Use of Temporary Employment in British Firms ${ }^{*}$}

This paper presents the first empirical evidence on the effect of the threat of unionisation on the use of a predominantly non-union type of employment, i.e. temporary employment. The identification strategy exploits an exogenous variation in union threat induced in the UK by new legislation enabling unions to obtain recognition even against the will of the management. The analysis finds no evidence of an effect on the probability that a firm employs fixed-term workers, and some weak evidence of a negative effect on the probability of using agency workers. Overall, therefore, there is no support for the hypothesis that firms under the threat of unionisation are more likely to use this type of non-union employment.

\section{NON-TECHNICAL SUMMARY}

There is substantial evidence that temporary workers are less likely to join a union than permanent workers. A firm that aims at forestalling unionisation might therefore be more prone to hire workers on temporary contracts. This paper looks at what happened in the UK when new legislation enabled unions in some firms to obtain recognition even against the will of the management. Did the firms which became exposed to this "threat of unionisation" react by hiring temporary workers? The data show no evidence of that.

JEL Classification: J51

Keywords: temporary employment, union threat, difference in difference

Corresponding author:

Andrea Salvatori

Institute for Social \& Economic Research

University of Essex

Colchester CO4 3SQ

United Kingdom

E-mail: a.salvatori79@gmail.com

\footnotetext{
* I thank prof. Mark Stewart and prof. Andrew Oswald for many useful discussions. I also thank participants at seminars at University of Warwick, University of Essex, University of Sheffield, University of Exeter, University of Bristol, University of Bath, EALE/SOLE 2010 world congress.
} 


\section{Introduction}

The potential effect of the threat of unionisation on employers' behaviour has long been acknowledged in Economics especially within the very large literature on union wage effects. In particular, several studies have attempted to identify the threat effect on non-union wages by using union density in industry/firms not covered by collective bargaining (Rosen, 1969; Freeman and Medoff, 1981; Lewis, 1986; Neumark and Wachter, 1995; Corneo and Lucifora, 1997). This approach, however, does not tackle the potential endogeneity of union threat since union density itself is likely to be correlated with unobservables that might affect wages in the workplace. Three more recent papers have therefore explored other identification strategies. DiNardo and Lee (2004) looked at the behaviour of wages in US firms where unions lost a recognition ballot by a small margin. Belfield and Heywood (2001) and Farber (2005) investigated the effects of the predicted probability of union membership (recognition) at the individual (firm) level in the UK and in the US respectively. This literature has produced mixed results, but the balance of the evidence seems to lend some support to the hypothesis that the threat of unionisation increases non-union wages.

The focus of the literature on the wage effects of the union threat is motivated by concerns that the estimates of union effects might be biased by threat effects. It is, however, clear that firms aiming at forestalling unionisation can also put in place explicit or implicit antiunion activities (Booth, 1995). Such activities are widely documented in the US as reported by DiNardo and Lee $(2004)^{1}$ and there is some indication of their presence in the UK as well (Dundon, 2002). Concerns have been raised in this latter country that union avoidance practices might become more widespread as a consequence of the legislation that since 2000 enables unions to obtain recognition in a workplace even against the will of the management (Oxenbridge et al., 2003). The recent increase in voluntary recognition agreements (ACAS, 2004; Blanden et al., 2006) suggests that the mere introduction of such provision has had an effect beyond its actual use by unions. In other words, the threat posed by the new statutory

\footnotetext{
${ }^{1}$ Such activities include firing activists, holding meetings to warn workers against the negative consequences of unionisation, employing consultants to provide advice on how to prevent unionisation, disputing the choice of the bargaining unit and so on.
} 
union recognition procedure has led some employers to recognise unions voluntarily. Other employers, however, might have tried to resist the reinvigorated threat of unionisation. This paper investigates the hypothesis that firms attempting to avoid unionisation have become more prone to hire workers who are less likely to join a union in the first place.

This paper makes several substantive contributions. First, it provides what appears to be the first empirical evidence on the effect of the threat of unionisation on a predominantly non-union type of employment, i.e. temporary employment. The evidence that temporary employees tend to be less unionised is clear. Using data from the Labour Force Survey for the UK, DTI (2005) reports that in 2004 (the most recent year considered in this paper) union density was $29.5 \%$ among permanent workers and $17.2 \%$ among temporary employees, with large differences both within the public (60.9\% vs $34 \%)$ and the private $(17.8 \%$ vs $7.1 \%)$ sector . Also data from the 2004 wave of the European Social Survey point at large differences in union density by contract type across Europe ${ }^{2}$. In addition, Eurofound (2010) reviewed the initiatives undertaken by unions to recruit new members and pointed out that temporary workers are reported to be very difficult to unionise across the $27 \mathrm{EU}$ countries and Norway.

Second, in focusing on temporary employment this paper also contributes to our understanding of the reasons behind the widespread use of limited-duration contracts in modern labour markets. The importance and relevance of the issues surrounding such type of employment both in Europe and in the US are testified by a growing body of literature (Autor, 2009; Booth et al., 2002; Arulampalam and Booth, 1998; Arulampalam et al., 2004; OECD, 2002; Kahn, 2007; Arulampalam et al., 2004; Brunello et al., 2007; Salvatori, 2010). In particular, some studies have looked at the relationship between unionisation and the use of temporary workers reporting mixed results. There is some evidence of a negative effect in the US with micro data (Gramm and Schnell, 2001; Houseman, 2001), but not with aggregate data (Autor, 2003). For Europe, evidence consistent with a positive effect is found in a number of EU countries and in particular in the UK (Bryson, 2007; Böheim and Zweimüller,

\footnotetext{
${ }^{2}$ In the UK, only $12 \%$ of workers on contracts of limited duration are union members, while union density is above $22 \%$ among permanent workers. Large differences are found even in countries with traditionally high union membership such as Sweden (68\% for permanent workers, $51 \%$ for temporary workers), Norway (59\% vs $28 \%$ ) and Finland (60\% vs $46 \%)$.
} 
2009; Salvatori, 2009). Of course, the variability in the estimates of the gross effect might well be due to the relative importance in different contexts of the different channels through which the effect of unions on temporary employment unfolds. For instance, unions may favour the presence of some temporary workers as a buffer for their permanent workers, but temporary workers can also be seen as a threat to union strength (Heery, 2004). For the UK, Böheim and Zweimüller (2009) interpret the fact that bargained wages are lower in the presence of agency worker as an indication that such workers are employed "against the union". However, firms employing agency workers might be low-wage firms for other reasons. More generally, disentangling the individual channels empirically is very difficult since it requires exogenous shocks that activate each of these independently - a very unlikely scenario. This paper makes some headway on this point by investigating whether firms use temporary workers "against unions" when exposed to an exogenous increase in the threat of unionisation. More broadly, the findings of this analysis can help reveal whether the available estimates of the effects of unions on temporary employment suffer from a threat bias.

A third contribution of this study lies in the original empirical strategy to identify the effect of the threat of unionisation. In particular, the paper uses data on private sector establishments from the Workplace Employment Relations Survey (WERS) to conduct a difference-in-difference analysis which exploits the fact that the statutory union recognition procedure introduced in 2000 only affected British firms with more than 20 employees. The underlying identification assumptions are carefully discussed and their credibility assessed within the constraints of the available data. The difference-in-difference analysis comparing firms above and below the 20-employee threshold is extended to use unionised firms as an additional control group in what is often referred to as a "triple-difference" analysis. This has the advantage of allowing for potential differences in underlying trends between smaller and larger firms, which in the standard difference-in-difference analysis are restricted to be the same. In addition, the availability of information on employment levels over time is exploited to search for any evidence of firms manipulating the level of employment in order to avoid the threat of unionisation. 
The results differ depending on the specific type of temporary contract considered. In fact, while for fixed-term workers there is no evidence of an effect, there is some support for the hypothesis of a negative effect of the threat of unionisation on the probability that firms employ agency workers. The estimates suggest a sizeable effect exceeding $-10 \%$. However, due to the limited size of the groups compared in the analysis these effects are not always estimated with high statistical precision. Overall, therefore, there is no evidence that firms which become exposed to the threat of unionisation react by hiring more temporary workers although they are known to be less likely to join a union.

\section{Literature}

The possible effect of the threat of unionisation on employers' behaviour in non-union firms has long been acknowledged in Economics, one of the earliest contributions being Lewis (1963). While Verma (2003) reviews some case studies that point to a role of union threats in the diffusion of employee voice systems in non-union firms, the vast majority of the literature has focused on its effects on wages. Farber (2005) briefly reviews some of the theoretical models that explicitly account for the fact that employers may want to forestall unionisation. The empirical literature on union threats has also mostly focused on wage effects. Most papers have attempted to identify the effect of union threat by looking at union density within sectors or firms not covered by collective bargaining. Using different versions of this approach, Rosen (1969); Freeman and Medoff (1981); Neumark and Wachter (1995) studied the union threat effects in the US. The evidence of these papers and that reported in the review by Lewis (1986) provides some support for the hypothesis that threat of unionisation increases wages in non-unions sectors or firms. Corneo and Lucifora (1997) report similar evidence for Italy. Belfield and Heywood (2001) offers the first study of the UK labour market using both data on union density at the industry level and workplace level data on the probability of becoming unionised ${ }^{3}$. They conclude that, on the one hand, non-union firms in highly unionised industries do tend to offer higher wages, but on the

\footnotetext{
${ }^{3}$ They use the 1998 wave of the Workplace Employment Relations Survey, which is also used in this paper.
} 
other hand the threat of unionisation does not induce the same wage compression within non-unionised firms which is observed in unionised firms.

Belfield and Heywood (2001) differ from most previous contributions in that they do not rely only on union density measures to identify the effect of the threat of unionisation. Two other recent papers using alternative identification strategies are those by DiNardo and Lee (2004) and Farber (2005), both of which use US data. In particular, DiNardo and Lee (2004) use an "event-study" approach that looks at workplaces where the unions lost the ballot to obtain recognition. They find evidence of little or no change in wages in the years leading up to the election. Farber (2005) reports no evidence of union threat effects as captured by the predicted probability of union membership, but finds empirical support for union threat effects when exploiting deregulation within three industries as a natural experiment. This paper adds to this literature by employing an original identification strategy which exploits the introduction of a statutory union recognition procedure in the UK as a source of exogenous variation in the threat of unionisation.

\section{The statutory union recognition procedure}

The empirical strategy of this paper exploits the introduction of a statutory union recognition procedure in the UK that enables a union to obtained recognition in a workplace even against the will of the management. Such provision was passed in July 1999 within the Employment Relations Act and came into effect in June $2000^{4}$. The Act sets out some requirements that must be met for a union to qualify to apply for recognition:

1. the employer must have at least 21 employees.

2. the union must show that at least $10 \%$ of employees in the proposed bargaining unit are Union members.

3. the union must convince the Central Arbitration Committee (CAC) that a majority of employees in the proposed bargaining unit are "likely" to support union recognition.

\footnotetext{
${ }^{4} \mathrm{~A}$ description of the main contents of the Act can be found in Oxenbridge et al. (2003)
} 
Once the CAC declares that a union is recognised the union is entitled to bargain over pay, hours, holidays and training issues.

The stated aim of this provision was to encourage voluntary recognitions (Wood and Goddard, 1999; Oxenbridge et al., 2003; Blanden et al., 2006). An official Government review (DTI, 2003) reports data from the British Trade Union Congress according to which 2000/2001 saw three times as many recognition agreements as 1999/2000. The report also states that a significant proportion of the cases which are brought before CAC end up with voluntary agreements anyway. Also revealing are the figures contained in the annual reports of the Advisory, Conciliation and Arbitration Service (ACAS), an independent UK public body that, intra alia, provides assistance to employers and unions which intend to reach an agreement on recognition in a non-confrontational and voluntary way. According to ACAS (2001), in the first few months following the introduction of the statutory procedure only 57 cases were brought before the CAC while ACAS dealt with 357 recognition conciliations, up from only 78 in 1999/2000 (and 57 in 1998/99). The number of cases dealt with by ACAS has remained high even in subsequent years (385 in 2001/02, 308 in 2002/03 and 236 in 2003/04 (ACAS, 2004)) while the CAC has continued to attend to far fewer cases (80 in 2002/2003 (ACAS, 2003) and 106 in 2003/04 (ACAS, 2004)). A general rise in voluntary recognitions has also been detected in survey data (Blanden et al., 2006) and it is likely to be one of the factors behind the end of the historically decreasing trend in union recognition in firms with more than 25 employees recorded in the 2004 wave of WERS (Kersley et al., 2005), the survey used in this paper. Overall therefore, there is strong indication that the new statutory procedure contained a "threat element" which in a number of cases induced employers to seek voluntary recognition agreements. The same threat might however have induced other employers to adopt union avoidance practices (Dundon, 2002; Oxenbridge et al., 2003).

As will become clear in section 4, the timing of the reform has important implications for the credibility of the empirical strategy adopted in this paper. It is therefore useful to provide some more details on the process by which the new legislation came to be adopted. The principle that a union should be recognised if a majority of workers in a given work- 
place voted in favour was stated in the 1997 Labour Manifesto which, however, did not mention any requirements that should be met by a firm/workplace for the new provision to be applicable. The 1998 White Paper on "Fairness at Work" did explicitly mention the 20-employees threshold. The paper was released in May 1998 following consultations with CBI and TUC, but did not contain a precise timetable for the actual implementation of the new statutory union recognition procedure.

\section{Empirical Strategy}

Following the introduction of the statutory union recognition procedure, unions can obtain recognition even against the will of the management in firms satisfying the requirements set out by the Employment Relations Act of 1999. This paper exploits the fact that only some firms became exposed to this "threat of unionisation" to try and identify its effect on the propensity of firms to use temporary employment.

The core of the empirical strategy is a simple difference-in-difference analysis that uses data on British establishments before (in 1998) and after (in 2004) the introduction of the statutory union recognition procedure. To begin with, the focus is restricted on the subsam-

ple of private sector firms with no recognised unions which are divided into a treated and a control group. The treated group include firms satisfying the requirements for the new procedure to be applicable. i.e. those which became exposed to the threat of unionisation as a result of the new legislation. While section 6 discusses the details concerning the definition of such groups, here suffice it to say that the treated group includes firms with more than 20 employees and is identified by the dummy variable Treated.

The difference-in-difference identification strategy compares the change over time in the outcome of the control group and the treated group. The relevant outcome here is the probability of using temporary employment. The estimate of the effect of interest can be obtained by estimating the following regression function:

$$
\text { Temp }_{i t}=\alpha+\beta_{1} \text { Treated }_{i t}+\beta_{2} \text { Post }_{i t}+\beta_{3} \text { Treated }_{i t} * \text { Post }_{i t}+\varepsilon_{i t}
$$


where $t=1998,2004$, and Temp is 1 if any temporary employees are employed and Post is a dummy for 2004. The coefficient $\beta_{1}$ picks up systematic differences between the treated and the control group and $\beta_{2}$ measures the time effects affecting both groups in the same way. Finally, $\beta_{3}$ is the coefficient of interest as it measures the extent to which the change in the outcome in the post-reform period differs between the treated and the control firms.

Since equation 1 represents a saturated model, the conditional expectation of the LHS variable is linear in the included regressors, fully justifying the use of OLS. The inclusion of additional controls does introduce potential complications. However, since most of the RHS variables employed in the analysis (and discussed in section 5) are discrete, a linear probability model can still be expected to provide a good approximation (Angrist and Pischke, 2009; Wooldridge, 2002). In light of this and given the advantages in terms of the ease of the interpretation over other models for binary outcomes, the empirical analysis uses OLS even when additional covariates are included.

The identification of the effect of the threat of unionisation relies on the assumption that the treated and the control group share a common trend. In other words, had the new legislation not been introduced, the propensity to use temporary employment would have changed in the same way for the two groups. The common trend is captured by the Post dummy. The deviation of the treated group from this common trend is picked up by the interaction Post $*$ Treated and interpreted as the effect of treatment. The commontrend assumption is generally more credible when changes in observable characteristics are accounted for by including additional controls into the basic model of equation 1.

Since the treated and the control groups are defined based on the 20 employees-threshold, the common-trend assumption here implies that firms above and below such threshold share a trend in the propensity to use temporary employment. Intuitively, the credibility of such assumption may depend on the upper limit chosen for the treated group, that is the one including firms with more than 20 employees. Hence, the sensitivity of the results to a number of upper-limits is checked as described in section 6 . When several time periods are available, one can further investigate the common-trend assumption by studying trends in the 
outcomes before the policy change (Angrist and Pischke, 2009). Unfortunately, the analysis of this paper can only rely on data from two points in time. Alternatively an additional control group can be used to account for a different underlying trend. I return to this below.

The identification of the causal effect of the threat of unionisation also rests on the assumption that there are no confounding effects from changes in the composition in unobservables. Since this assumption would be violated if subjects could move between the treated and the control group this is often referred to as the "no-movers assumption" (Lee, 2005). Assessing its credibility is particularly important when using repeated cross-sections given the lack of convincing ways to account for unobserved heterogeneity. In light of this, I first follow the previous literature by checking the robustness of the results to the exclusion of potential movers (Angrist and Pischke, 2009; Kugler et al., 2005; Kugler and Pica, 2008). I then investigate if there is any evidence of firms manipulating employment around the 20-threshold set out by the law for the applicability of the new statutory union recognition procedure. The details of this are described in section 6.1 .

This latter check also provides a way to investigate another potential problem that might affect the empirical analysis of this paper, namely the possibility that some firms may have modified the level of employment even before the implementation of the new policy. Such anticipatory behaviour could alter the composition of the treated and the control group in a way that could confound the estimates of the effect of the policy even in the absence of movers across two time periods considered (Blundell and Dias, 2009). The availability of data on the level of employment in different years before the introduction of the new legislation provides the opportunity to verify the existence of such anticipatory behaviour.

\subsection{Triple-difference}

Since the groups are defined based on the employment level, the common-trend assumption discussed in the previous section requires small and large firms to share a trend in the propensity to use temporary employment. Clearly, controlling for employment in the difference-in-difference regressions make this assumption more credible as it removes the ef- 
fect of employment per se. However, this does not account for the possible differences in trends in the propensity to use temporary employment between firms with different levels of employment. Hence, the difference-in-difference estimate could still confound the true effect of the policy and the time effect affecting all firms with more than 20 employees. To try and disentangle the former from the latter, an additional control group is required.

For the purpose of this paper, any unionised firm is non-treated and can be part of an additional control group. In particular, unionised firms with more than 20 employees can be exploited to try and isolate any time effect affecting all firms with more than 20 employees, regardless of their union status. The model of interest can then be written as:

$$
\begin{aligned}
& \text { Temp }_{i t}=\alpha+\beta_{1}{\text { Above } 21_{i t}+\beta_{2} \text { NonUnion }_{i t}+\beta_{3} \text { Post }_{i t}+\beta_{4} \text { Above } 1_{i t} * \text { NonUnion }_{i}(2)}(2) \\
& \beta_{5}{\text { Post } * \text { Above } 1_{i t}+\beta_{6} \text { Post } * \text { NonUnion }}_{\text {it }} \\
& +\beta_{7}{\text { Post } * \text { Above } 1_{i t} * \text { NonUnion }_{i t}}+\varepsilon_{i t}
\end{aligned}
$$

This model now accounts for time effects affecting all groups (Post), common trends between firms with more than 20 employees (Post $*$ Above21) and common trends between non-unionised firms (Post $*$ NonUnion). The interaction Above $21_{i t} *$ NonUnion $_{i t}$ identifies the same firms as the Treated dummy in equation 1. The coefficient of interest in this case is $\beta_{7}$ which measures the change in the propensity to use temporary employment after treatment for the treated group. This can be interpreted as the difference between two difference-in-difference estimators, hence the name "triple difference" found in the literature (Hamermesh, 2000; Lee, 2005). The first difference-in-difference compares non-unionised firms above and below the 20-employee threshold and identifies the sum of the treatment effect and a time*Above21 effect $\left(\beta_{5}+\beta_{7}\right)$. The second one compares unionised firms below and above the threshold and identifies only the time* Above21 effect $\left(\beta_{5}\right)$ since neither of these groups were treated. It follows that the difference between these two yields the pure treatment effect $\beta_{7}$. Clearly, the identification assumption here is that unionised and nonunionised firms with more than 20 employees share a common trend picked up by $\beta_{5}$. Under 
this assumption, any effect captured by the coefficient on the interaction Post * Above21* NonUnion can be interpreted as the treatment effect.

\section{Data and specification}

The data used in this paper come from the management questionnaires of the 1998 and 2004 waves of the Workplace Employment Relations Survey (WERS). The two independent crosssections are appended and only the subsample of workplaces operating in the private sector with more than 10 employees is retained. Since WERS is a complex survey, weights are used throughout the analysis to account for stratification and clustering. Since the difference-indifference analysis of this paper only compares two groups over two time periods, there is no convincing way to address the potential within-group and over-time correlation which has attracted much attention in the recent literature (Imbens and Wooldridge, 2008; Angrist and Pischke, 2009).

The number of controls that can be included in the regression analysis is limited by issues of comparability between the two waves. The difference-in-difference estimates reported below are all obtained from specifications including controls for the level of employment, age of the establishment, and occupation shares. Moreover, I always include dummies for independent establishments, establishments producing more than one product, market shares, geographical market (regional, national, international), presence of foreign competition, pres-

ence of cost targets, industry and regions. As discussed in section 4, a number of linear probability models are estimated and three different dependent variables are considered. In particular, FixT is a dummy for the presence of fixed-term workers in the workplace, $T A W$ is a dummy for the presence of agency workers and finally AnyTemp is a dummy for the presence of fixed-term or agency workers. 


\section{Definitions of control and treated groups}

The analysis begins by comparing the behaviour over time of two groups of non-unionised firms. The treated group is made up of firms which became exposed to the threat of unionisation as a result of the introduction of the new statutory union recognition procedure. The precise definition of such groups depends of course on the requirements set by the law but must also be informed by the assumptions needed for the difference-in-difference estimator to identify the causal effect of the threat of unionisation. In particular, care must be taken to ensure the credibility of the two fundamental assumptions discussed in section 4, namely those of common trends and lack of movers across the treated and control groups.

One of the requirements set out by the law for the statutory union recognition procedure to be applicable is that at least $10 \%$ of employees in the proposed bargaining unit must be union members. Not surprisingly, the data do not allow me to identify such (potential) "bargaining units" within a workplace. On the other hand, measures of union membership at the workplace level are available in WERS, but very few firms not recognising a union report the presence of union members. For example, in the 2004 cross-section there are no more than 88 non-unionised firms with 21 to 100 employees and at least some union members. Moreover, serious concerns can be raised on the reliability of measures of union membership as reported by the managers of firms that do not recognise any unions. In light of these issues, the treated and the control groups are defined using only the employment level. This can possibly result in an attenuation bias since it effectively inflates the treated group at the expense of the control group.

The lower employment limit for the treated group is set out by the law (21 employees), but the upper limit must be chosen to enhance the credibility of the common-trend assumption underlying the difference-in-difference approach. This suggests choosing a low upper limit to ensure that the control and the treated firms are not too different in terms of employment levels. On the other hand, lowering the upper-limit reduces cell-sizes. For this reason, the empirical analysis considers a number of alternative upper limits for the employment level of the treated group and verifies the robustness of the results to each of them. 
Another issue to be considered is the time period of the level of employment used to define the groups. This is a potentially important point to ensure that neither group suffers from self-selection. To try and mitigate this problem, the existing literature has either used information on the pre-reform period to define the treated and control group or has excluded movers across groups over time completely (Angrist and Pischke, 2009; Kugler et al., 2005; Kugler and Pica, 2008). The availability of information on past employment levels in each of the two waves of WERS makes it possible to pursue this latter approach in this paper as well.

Using past information to define the groups does not necessarily solve the self-selection problem if firms started to adjust employment early in anticipation of the new legislation (Blundell and Dias, 2009). For the analysis of this paper, this means that firms would have started to adjust employment as early as 1998 in anticipation of a reform that came into effect in 2000. This seems rather unlikely especially in light of the fact that the relevant threshold of 20 employees was first mentioned in an official government document in 1998. Nevertheless, the availability of information on past employment in both waves of WERS provides an opportunity to test the hypothesis that firms changed the level of employment in response to the new legislation.

\subsection{Did firms change the level of employment?}

The two waves of WERS contain information on past employment (in 1993 and 1997 for the 1998 wave, and in 1998 and 2003 for the 2004 wave). This provides the opportunity to investigate the hypothesis that non-unionised firms around the 20-employee threshold modified their level of employment in response to or in anticipation of the statutory union recognition procedure. This will be referred to as the "movers hypothesis". The first set of tests considered are based on the idea that firms just above and just below the 20-employee threshold would behave differently under this hypothesis. In particular, in order to avoid being subject to the new provision, firms just above the threshold would tend to decrease employment, while firms just under the threshold would resist increasing the number of 
employees. The tests therefore look at differences in the probabilities of increasing/decreasing employment between firms on the two sides of the 20-employee threshold.

To see how a formal test can be conducted, focus first on the probability of decreasing employment. Let EmplDown_tx be 1 if a firm decreased employment between $t-x$ and $t$. Then consider the following simple regression:

$$
\text { EmplDown_tx } x_{i}=\alpha+\beta_{1} E m p l \_t x_{-} 16 \_25_{i}+\beta_{2} E m p l \_t x \_21_{-} 25_{i}+\varepsilon_{i}
$$

where $E m p l \_t x_{-} 16 \_25$ is a dummy taking the value 1 if the level of employment at $t-x$ was between 16 and 25 employees, and Empl_tx_21_25 $5_{i}$ is 1 if employment at $t-$ $x$ was between 21 and 25 employees. The coefficient $\beta_{2}$ therefore captures the difference between firms with 21 to 25 employees and those with 16 to 20 employees. Under the movers hypothesis, one would expect $\beta_{2}>0$. In the empirical analysis this equation is extended to control for employment at $t-x$, industry and region dummies. When carried out using the 1998 sample and $x=1$, this can be taken as a test that firms anticipated the policy. On the 2004 sample with $x=6$, this is a test for the presence of movers.

This test rests on the assumption that in the absence of the policy change firms just above and just below the 20-employee threshold would have behaved in the same way. To account for the possibility that these two groups might have behaved differently even in the absence of the new legislation, one needs to find two other groups that offer a good approximation of this missing counterfactual. One possibility is to consider groups of firms just above and below another threshold that has nothing to do with the statutory union recognition procedure. In order to ensure comparability, it appears reasonable to choose a "fake" threshold not too far from 20. For example, one can compare the difference between firms around the 20-employee threshold with the difference between firms around the 30-employee threshold. This can be done in a linear regression that reads as follow:

$$
\begin{aligned}
\text { EmplDown } \_t x_{i}= & \alpha+\beta_{1} E m p l \_t x_{-} 16 \_25_{i}+\beta_{2} E m p l \_t x \_26 \_35_{i}+ \\
& \beta_{3} E m p l \_t x \_d 1_{-} d 5_{i}+\beta_{4} E m p l \_t x \_21 \_25_{i}+\varepsilon_{i}
\end{aligned}
$$


where the dummies are constructed following the same logic as in equation 3 and $E m p l \_t x_{\_} d 1_{-} d 5_{i}$ is 1 if employment at $t-x$ was between 21 and 25 employees or between 31 and 35 employees. Using this equation, one can write:

$$
\begin{aligned}
& E\left[E m p l D o w n \_t x_{i} \mid E m p l \_t x \in(16,20)\right]=\alpha+\beta_{1} \\
& E\left[E m p l D o w n \_t x_{i} \mid E m p l \_t x \in(21,25)\right]=\alpha+\beta_{1}+\beta_{3}+\beta_{4} \\
& E\left[E m p l D o w n \_t x_{i} \mid E m p l \_t x \in(26,30)\right]=\alpha+\beta_{2} \\
& E\left[E m p l \text { Down_tx } \mid E m p l \_t x \in(31,35)\right]=\alpha+\beta_{2}+\beta_{3}
\end{aligned}
$$

Hence, the coefficient $\beta_{4}$ is effectively a difference-in-difference estimator comparing the difference between firms above and below the 20-employee threshold (eq. 6- eq. 5) and the difference between firms below and above the 30-employee threshold (eq. 8- eq. 7). A positive $\beta_{4}$ is consistent with the hypothesis that firms reacted (in anticipation) to the statutory union recognition provision.

Two alternative comparison groups are provided by unionised firms around the 20employee threshold. To use these groups, one can estimate the model:

$$
\begin{aligned}
\text { EmplDown } \_t x_{i}= & \alpha+\beta_{1} E m p l \_t x \_16 \_25_{i}+\beta_{2} E m p l \_t x \_21 \_25_{i} \\
& \beta_{3} E m p l \_t x \_16 \_25_{i} * N o U n i o n+\beta_{4} E m p l \_t x{ }_{-}{ }^{21}{ }_{-} 25_{i} * N o U n i o n \\
& \beta_{5} N o U n i o n+\varepsilon_{i}
\end{aligned}
$$

on the sample including both unionised and non-unionised firms (with union status constant between $t-x$ and $t$ ). The dummy NoUnion is 1 if there are no recognised unions in the workplace. The coefficient of interest $\beta_{4}$ is again a difference-in-difference estimator. It compares the difference in the probability of lowering employment between non-unionised firms around the 20-employee threshold with the difference in the same probability between unionised firms around the same employment threshold. The expected sign of $\beta_{4}$ under the anticipation/movers hypothesis is again positive. 
Finally, the availability of information on other time periods provides yet another candidate counterfactual for the difference between firms around the 20-employee threshold. In particular, one can compare the change in employment between 1997 and 1998 with that between 2003 and 2004 for non-unionised firms just below and just above the 20-employee threshold. For this to offer a useful test two assumptions must be made. The first one is that by 2003 (that is, 3 years after the new regulations came into force) firms had already fully adjusted their employment to avoid being subject to the provisions of the Employment Relations Act. The second one is that the 2003-2004 change in employment provides a good representation of what would have happened in 1997-1998 in the absence of anticipatory behaviour. Similarly, for the change in employment between 1998 and 2004 , a possible control is provided by the change in employment between 1993 and 1998. The underlying assumption here is that the difference in the probability of decreasing employment between firms just above and just below the 20-employee threshold would have been the same in19982004 as it was in 1993-1998. These tests can be conducted by estimating the following linear model on the subsample of non-unionised firms:

$$
\begin{aligned}
\text { EmplDown } \_t x_{i y}= & \alpha+\beta_{1} E m p l \_t x_{-} 16_{-} 25_{i y}+\beta_{2} E m p l \_t x_{-}{ }^{21} \_25_{i y} \\
& \beta_{3} \text { Empl_tx_16_25 } 5_{i y} * \text { Post }+\beta_{4} E m p l \_t x_{-}{ }^{21}{ }_{-} 25_{i y} * \text { Post } \\
& +\beta_{5} \text { Post }+\varepsilon_{i}
\end{aligned}
$$

where now the subscript $y=1998,2004$ and Post is a dummy which is 1 for 2004 . The coefficient of interest is of course $\beta_{4}$. When $x=1$, the model compares differences in changes in employment between 2003 and 2004 with those between 1997 and 1998. Hence, in this case $\beta_{4}<0$ is consistent with firms adjusting employment in anticipation of the new legislation ${ }^{5}$.When comparing changes in employment between 1993 and 1998 with those between 1998 and $2004, \beta_{4}>0$ is consistent with firms reacting to the introduction of the new legislation by changing their employment to avoid the threat of unionisation.

\footnotetext{
${ }^{5} \mathrm{~A}$ negative $\beta_{4}$ means that firms just above 20 employees were more likely to reduce employment (when compared with firms just below 20 employees) in 1997-98 than in 2003-04, when we are assuming there was no reaction to the new legislation anymore.
} 
Similar tests can be conducted looking at the probability of increasing employment of firms just below 20 employees. Under the movers hypothesis, these firms should be less likely to increase employment than those with more than 20 employees. Tests that parallel those just described can be performed by estimating the following equations:

$$
E m p l U p \_t x_{i}=\alpha+\beta_{1} E m p l \_t x \_16 \_25_{i}+\beta_{2} E m p l \_t x \_16 \_20_{i}+\varepsilon_{i}
$$

The movers assumption would imply that $\beta_{2}<0$. To use firms around the 30-employee threshold as comparison groups, one can estimate the model:

$$
\begin{aligned}
E m p l U p \_t x_{i}= & \alpha+\beta_{1} E m p l \_t x_{-} 16 \_25_{i}+\beta_{2} E m p l \_t x_{-} 26_{-} 35_{i}+ \\
& \beta_{3} E m p l \_t x_{-} d 6 \_d 0_{i}+\beta_{4} E m p l \_t x_{-} 16 \_20_{i}+\varepsilon_{i}
\end{aligned}
$$

To use unionised firms around the 20-employee threshold as comparisons groups, the following model can be estimated:

$$
\begin{aligned}
& E m p l U p \_t x_{i}=\alpha+\beta_{1} E m p l \_t x_{-} 16 \_25_{i}+\beta_{2} E m p l \_t x \_16 \_20_{i} \\
& \beta_{3} E m p l \_t x \_16 \_25_{i} * \text { NoUnion }+\beta_{4} E m p l \_t x \_16 \_20_{i} * \text { NoUnion } \\
& \beta_{5} \text { NoUnion }+\varepsilon_{i}
\end{aligned}
$$

In both equations 12 and $13 \beta_{4}<0$ is consistent with the movers hypothesis.

Finally, to exploit the availability of different time periods one can resort to:

$$
\begin{aligned}
E m p l U p \_t x_{i y}= & \alpha+\beta_{1} E m p l \_t x_{-}{ }^{16}{ }_{-} 25_{i y}+\beta_{2} E m p l \_t x \_16 \_20_{i y} \\
& \beta_{3} E m p l \_t x \_16 \_25_{i y} * \text { Post }+\beta_{4} E m p l \_t x_{-} 16 \_20_{i y} * \text { Post } \\
& \beta_{5} \text { Post }+\varepsilon_{i}
\end{aligned}
$$

When the focus is on the 1997-98 (2003-04) employment change, $\beta_{4}>0\left(\beta_{4}<0\right)$ is consistent with the movers hypothesis. 


\subsection{Cell sizes and evidence on employment manipulation}

Table 1 and 2 report cell sizes for both the treated (T) and the control (C) group before and after the introduction of the statutory union recognition procedure respectively. These groups are based only on the level of employment and include non-unionised firms in the private sector with more than 10 employees. For 2004, two different definitions are presented in the two panels of table 2. The first defines the $\mathrm{T}$ and $\mathrm{C}$ groups based on the level of employment in 2004, while the second one checks that the conditions are met in both 1998 and 2004. Hence, this latter definition completely exclude movers. The control group always include firms with 10 to 20 employees, while for the treated groups several upper limits are considered as indicated in each column in tables 1 and 2 . In general, it appears that the treated group is not very large and there is a clear trade-off between cell sizes and excluding movers.

Table 3 reports the results of the tests based on equations 3 through 10. The dependent variable is a dummy for having decreased employment and the reported coefficients are the ones comparing non-unionised firms just above 20 employees with those just below 20 employees. The first row refers to the simple comparison between these two groups, while the remaining three use additional comparison groups, namely (i) non-unionised firms around the 30-employee threshold (ii) unionised firms around the 20-employee threshold and (iii) non-unionised firms around the 20-employee threshold in another time period. In all cases the reported coefficients are obtained controlling for employment in the previous period and for industry and region dummies. Table 4 follows the same structure but reports the results for the probability of increasing employment. In this table the reported coefficients allow to see how firms just below the 20 employee threshold behaved compared to those just above it.

The first coefficient in the top panel of table 3 indicate that firms just above the 20employee threshold were more likely to decrease employment between 1997 and 1998 than firms just below the threshold. This estimate is large $(+26 \%)$ and statistically significant. To check the robustness of this first result, the second coefficient in the same panel is obtained 
using firms around the 30-threshold as control groups. The point estimates is still positive and statistically significant at the $5 \%$ level. Using unionised firms around the 20-employee threshold as a control group, on the other hand, leads to smaller positive coefficient which is statistically insignificant. Finally, the fourth coefficient in the top panel of table 3 indicates that firms with 21 to 25 employees were more likely to decrease employment between 1997 and 1998 than they were between 2003 and 2004. All of these estimates are consistent with the hypothesis that firms changed the level of employment to avoid the forthcoming threat of unionisation. The evidence is less clear, however, when the outcome of interest is the probability of increasing employment and the focus is on the behaviour of firms with less than 20 employees. The movers hypothesis in this case would imply that these firms should be less likely to increase their employment. However, the coefficients reported in the top panel of table 4 all have large p-values and their signs do not tell a consistent story across different models.

In the bottom panel of table 3, the positive coefficient obtained comparing firms with 21 to 25 employees to those with 16 to 20 employees is consistent with the hypothesis of movers between 1998 and 2004. However, the estimate is small and highly statistically insignificant. The proposed corrections for possible biases do not provide any stronger evidence. When using firms around the 30-threshold and unionised firms as control groups, I obtain contradicting signs and again statistically insignificant estimates. The last reported coefficient attracts a negative sign which is consistent with the movers hypothesis, but is again statistically insignificant. The bottom panel of table 4 presents again mixed results with the second, the third, and fourth coefficients showing a sign that indicates that firms under 20 employees were less likely to increase employment. Again, all the coefficients are statistically insignificant.

Overall, therefore, there is some evidence of anticipatory behaviour in 1998 but not of movers between 1998 and 2004. Some of the differences found in this exercise might, of course, be accounted for by firm characteristics that cannot be controlled for here due to data limitation, but that are taken into account in the main analysis of the paper. As already 
mentioned, the robustness of the results to the exclusion of movers is checked throughout the analysis, although this exacerbates the problem of small cell sizes. Unfortunately, there is no obvious solution to the problem posed by the possible anticipatory behaviour of firms in 1998 and the direction of the bias that this might generate cannot be established with certainty. One plausible scenario is that the firms that did change the level of employment in anticipation of the new legislation are those which are more sensitive to the threat of unionisation. Hence, they might have been even more likely to react to the union threat had they not avoided it. This would result in attenuation bias in the estimate of the effect of the threat of unionisation.

\section{Results}

The difference-in-difference estimate of the effect of the union threat on the use of temporary employment are reported in tables 5 and 6 for the probability of fixed-term workers and agency workers respectively ${ }^{6}$. In all cases the coefficient of interest is the one on the Treated* Post interaction. Each table reports the results for the two definitions of the treated group and for a number of alternative upper-limits for the level of employment of the treated group.

For the probability of using fixed-term workers, table 5 shows that the coefficient of interest is generally positive but its size appears sensitive to different definitions of the treatment group and its standard errors are always too large to reach statistical significance at any conventional level. On the other hand, for agency workers table 6 shows some weak evidence of a negative effect of the introduction of the statutory union recognition provision. The estimated Post $*$ Treat coefficient is consistently negative and its size is relatively stable when firms with more than 31 employees are included in the sample, as showed in the last three columns of the table. The similarity of the estimates across panels indicate that the results are not very sensitive to the exclusion of potential movers. Also, some of the coefficients are estimated precisely enough to reach statistical significance at the $10 \%$ or

\footnotetext{
${ }^{6}$ Results for the probability of employing either type of temporary workers are not reported here but are summarised in other footnotes below. These results are available from the author.
} 
even 5\% significance level. Most estimates, and in particular those statistically significant, are in the neighborhood of a $-10 \%$ effect.

These estimates are obtained by comparing non-unionised firms above and below the 20employee threshold ${ }^{7}$. To try and control for differences in underlying trends between smaller and larger firms, an additional control group made up of unionised firms with more than 20 employees can be exploited. This leads to the "triple-difference" estimates of the effect of the threat of unionisation which are reported in tables 7 and 8 for the two probabilities of interest $^{8}$. In these tables, the coefficient picking up the effect of the union threat is that on the triple interaction Post $*$ NonUnion $*$ Above 21 .

The results in table 7 show that the estimate of the effect of the threat of unionisation on the probability of using fixed-term workers is now negative in both the top and the bottom panels. The positive coefficients attracted by the Post $*$ Above 21 interaction suggests that the difference-in-difference estimates of table 5 confounds the trend in larger firm with the effect of interest ${ }^{9}$. None of these coefficients, however, is estimated with statistical precision. Conversely, higher precision is attained when looking at the probability of using agency workers. In table 8, the triple-difference estimates are still negative but larger in magnitude than the difference-in-difference estimates. The results in the top panel (where the problems posed by potential movers are ignored) and the bottom panel (where movers are excluded) consistently indicate an effect not far from $-20 \%$ which is statistically significant in the last two columns of the top panel and is associated with a $p$-value below $20 \%$ in most of the other cases. The loss of statistical precision in this triple-difference exercise is largely expected. In fact, in spite of the larger sample size due to the inclusion of non-unionised firms in the sample, the size of the treated group remains the same although the treated

\footnotetext{
${ }^{7}$ Not surprisingly, the results for the probability of using either fixed-term or agency workers (vs neither of them) are mixed and inconclusive. These results are available from the author upon request.

${ }^{8}$ All the regressions presented in tables 7 and 8 were also ran excluding from the sample unionised firms in 2004 which had become unionised in the previous 6 years (the only time span considered in the 2004 questionnaire). This is an attempt to mitigate the problem of movers between the unionised and nonunionised group in response to the statutory union recognition procedure. The results obtained in this fashion are substantially the same as the ones reported here and are available from the author upon request.

${ }^{9}$ The coefficients in table 7 do not add up exactly to those in table 5 because the use of different samples imply a different set of restrictions on the coefficients of the other covariates.
} 
firms are now used to estimate more parameters ${ }^{10}$.

To sum up, the results differ between the two types of temporary workers considered in the analysis. For fixed-term workers, there is no evidence of an effect of the threat of unionisation since the difference-in-difference and the triple-difference results differ in signs, vary considerably across definitions of the treated group and are never statistically significant. On the other hand, there is tentative evidence that the threat of unionisation decreases the probability that firms use agency workers. The estimated effect is negative in both the difference-in-difference and the triple-difference analysis. The former suggests a $-10 \%$ effect, while the latter a $-20 \%$ effect and neither estimates appear very sensitive to the exclusion of potential movers. However, as one would expect in light of the limited cell sizes discussed in section 6.2, statistical precision is not always high particularly in the triple-difference analysis.

\section{Discussion of results}

This paper has exploited the introduction in the UK of a statutory union recognition procedure to identify the effect of the threat of unionisation on the propensity of firms to use temporary employment. Since such a procedure can only be applied in firms with more than 20 employees, a difference-in-difference estimator has been used to compare non-unionised firms above and below that threshold. While there is no evidence of an effect on the probability of using fixed-term workers, the analysis has provided some support in favour of the hypothesis that firms that came to be exposed to the threat of unionisation became less likely to use agency workers.

The causal interpretation of such finding rests on two fundamental assumptions. The first one is that the propensity to use agency workers in the absence of the new legislation would have changed in the same way in the treated and in the control group. The credibility of the results is reinforced by the use of a triple-difference estimator which accounts for possible

\footnotetext{
${ }^{10}$ The results for the probability of employing any type of temporary workers now more clearly points at a negative effect of the threat of unionisation although, again, statistical significance is never attained. These results are available from the author.
} 
differences in trends between larger and smaller firms. This set of results is generally less statistically significant but suggests an even stronger negative effect of around $-20 \%$.

The second assumption underlying the causal interpretation of the difference-in-difference estimate is that the composition of the treated and the control group remained stable over time. Some simple tests revealed no evidence that firms manipulated the level of employment between 1998 and 2004 to avoid the threat of unionisation. Moreover, both the differencein-difference and the triple-difference results show relatively little sensitivity to the exclusion of potential movers from the sample. There is however some indication in the data that firms might have manipulated the level of employment as early as 1998. The hypothesis that this might have happened in anticipation of the forthcoming legislation appears rather unlikely, but cannot be ruled out. No obvious solution to this potential problem can be applied with the available data. As for the direction of the bias that this might generate in the estimate of interest, it clearly depends on how these firms would have behaved had they not left the treated group. One plausible possibility is that they would have been even more likely to react to the threat of unionisation than those which remained in the treated group. Under this assumption, this anticipatory behaviour may produce an attenuation bias in the estimate of the effect of the union threat. Another source of a potential bias towards zero is the fact that due to data limitation the treated group could only be defined based on employment while the requirement in terms of presence of union members had to be ignored as discussed in section 6 .

Overall, therefore there is no evidence that firms use (less unionised) temporary employees to avoid the threat of unionisation. A possible explanation of the negative effect found for agency workers is offered by previous evidence on the relationship between permanent workers and temporary workers. Pearce (1993), Broschak and Davis-Blake (2006) and Kraimer et al. (2005) report evidence that permanent employees working alongside temporary employees have less trust in the organization, increased turnover intensions and often perceive their temporary co-workers as a threat. A firm concerned about the possibility that workers could organize a union may therefore be reluctant to employ temporary workers. 
Cast in the framework of the research on the relationship between unionisation and the use of temporary employment, this result can be read as evidence against the hypothesis that firms use (less unionised) temporary employees to weaken a union. Clearly the behaviour of firms once a union has been established might well differ, but this result certainly does not provide support for the hypothesis that the positive effect of unions on the probability that firms use temporary workers (Bryson, 2007; Böheim and Zweimüller, 2009; Salvatori, 2009) is driven by the fact that such employees are hired "against the union". More broadly, in light of these results it appears unlikely that the desire of firms to avoid unionisation is one of the major determinants of the widespread use of temproary contracts across Europe.

\section{Conclusion}

This paper has presented the first study of the effect of the threat of unionisation on the propensity of firms to use a predominantly non-union type of employment, i.e. temporary employment. The identification strategy has exploited the exogenous variation in the threat of unionisation generated by the introduction of a statutory union recognition procedure in the UK.

The results differ depending on the specific type of temporary contract considered. In fact, while for fixed-term workers there is no evidence of an effect, there is some support for the hypothesis of a negative effect of the threat of unionisation on the probability that firms employ agency workers. The estimates suggest a sizeable effect exceeding $-10 \%$. However, due to the limited size of the groups compared in the analysis these effects are not always estimated with high statistical precision.

Overall, therefore, there is no evidence that firms which become exposed to the threat of unionisation react by hiring non-union employment. 
Table 1: Control and Treated group before treatment, defined using the level of employment (WERS 1998)

\begin{tabular}{llllll}
\hline \hline Max Empl for T: & 26 & 31 & 36 & 41 & 46 \\
\hline Employment 1998 & & & & & \\
$\mathrm{T}$ & 56 & 113 & 162 & 200 & 236 \\
$\mathrm{C}$ & 125 & 125 & 125 & 125 & 125 \\
None & 743 & 686 & 637 & 599 & 563 \\
\hline \hline
\end{tabular}

Non-unionised, private sector workplaces.

T group: employment between 21 and max empl.

C group: 10-20 employees.

None: employment $>$ treated group.

Table 2: Control and Treated group after treatment, defined using the level of employment (WERS 2004)

\begin{tabular}{llllll}
\hline \hline Max Empl for T: & 26 & 31 & 36 & 41 & 46 \\
\hline T based on empl. in & $\mathbf{2 0 0 4}$ & & & \\
T & 63 & 119 & 160 & 187 & 216 \\
C & 245 & 245 & 245 & 245 & 245 \\
None & 843 & 787 & 746 & 719 & 690 \\
\hline T based on empl. in & $\mathbf{1 9 9 8}$ & and & $\mathbf{2 0 0 4}$ & \\
T & 5 & 29 & 47 & 61 & 74 \\
C & 99 & 99 & 99 & 99 & 99 \\
None & 647 & 623 & 605 & 591 & 578 \\
\hline \hline
\end{tabular}

Non-unionised, private sector workplaces.

T group: employment between 21 and max empl.

C group: 10-20 employees.

None: employment $>$ treated group. 
Table 3: Estimates from a linear model for the probability of decreasing employment in firms with 21 to 25 employees

\begin{tabular}{lllll}
\hline \hline \multicolumn{1}{c}{ Coeff } & SE & \multicolumn{2}{c}{ P-Value } & Obs \\
\hline Empl change between 1997 and 1998 \\
$\beta_{2}$ in eq (3) & 0.261 & 0.123 & 0.034 & 886 \\
$\beta_{4}$ in eq (4) & 0.373 & 0.162 & 0.021 & 886 \\
$\beta_{4}$ in eq (9) & 0.119 & 0.281 & 0.670 & 1445 \\
$\beta_{4}$ in eq (10) & -0.235 & 0.161 & 0.143 & 1822 \\
\hline \hline Empl change between 1998 and 2004 \\
$\beta_{2}$ in eq (3) & 0.042 & 0.127 & 0.741 & 624 \\
$\beta_{4}$ in eq (4) & 0.133 & 0.190 & 0.483 & 624 \\
$\beta_{4}$ in eq (9) & -0.300 & 0.218 & 0.168 & 966 \\
$\beta_{4}$ in eq (10) & -0.130 & 0.196 & 0.510 & 1288 \\
\hline \hline
\end{tabular}

Table 4: Estimates from a linear model for the probability of increasing employment in firms with 16 to 20 employees

\begin{tabular}{|c|c|c|c|c|}
\hline Coeff & $\mathrm{SE}$ & \multicolumn{2}{|c|}{ P-Value $\mathrm{Ob}$} & \\
\hline \multicolumn{5}{|c|}{ Empl change between 1997 and 1998} \\
\hline$\beta_{2}$ in eq $(11)$ & 0.037 & 0.110 & 0.738 & 886 \\
\hline$\beta_{4}$ in eq $(12)$ & 0.063 & 0.175 & 0.720 & 886 \\
\hline$\beta_{4}$ in eq $(13)$ & -0.145 & 0.262 & 0.579 & 1445 \\
\hline$\beta_{4}$ in eq $(14)$ & -0.088 & 0.145 & 0.543 & 1822 \\
\hline \multicolumn{5}{|c|}{ Empl change between 1998 and 2004} \\
\hline$\beta_{2}$ in eq $(11)$ & 0.030 & 0.123 & 0.806 & 624 \\
\hline$\beta_{4}$ in eq $(12)$ & -0.046 & 0.189 & 0.806 & 624 \\
\hline$\beta_{4}$ in eq $(13)$ & -0.184 & 0.253 & 0.467 & 966 \\
\hline$\beta_{4}$ in eq $(14)$ & -0.066 & 0.188 & 0.726 & 1288 \\
\hline \multicolumn{5}{|c|}{ Model equations in section 6.1} \\
\hline \multicolumn{5}{|c|}{ Controls: region and industry dummies, past empl. } \\
\hline \multicolumn{5}{|c|}{ Weights account for complex design. } \\
\hline
\end{tabular}


Table 5: Estimates from a linear probability model for the probability of any fixed-term workers in the workplace.

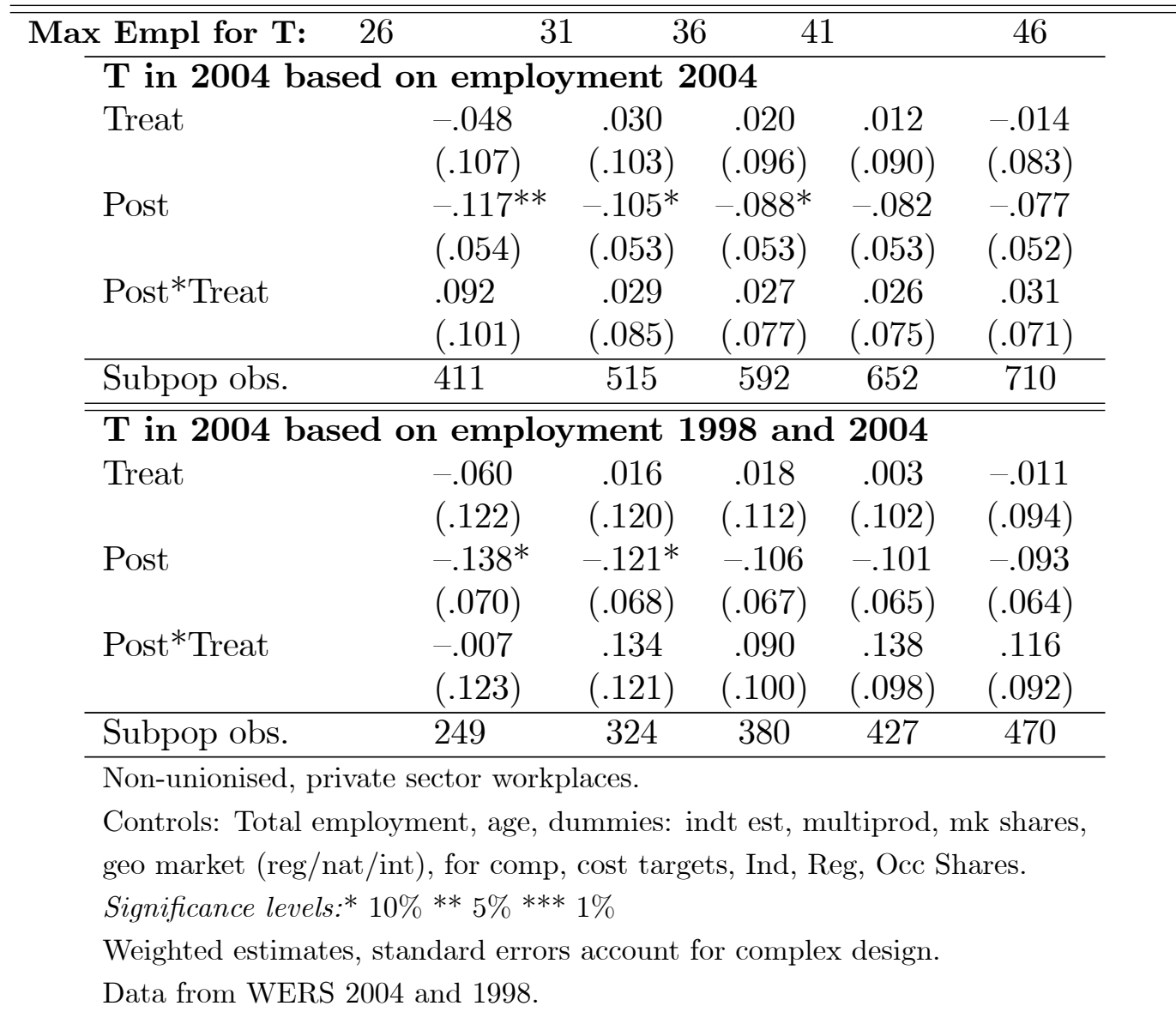


Table 6: Estimates from a linear probability model for the probability of any agency workers workers in the workplace.

\begin{tabular}{|c|c|c|c|c|c|c|}
\hline Max & Empl for T: 26 & 31 & 36 & 41 & & 46 \\
\hline & $T$ in 2004 base & n empla & oyment & 2004 & & \\
\hline & Treat & .016 & .053 & .068 & .072 & .083 \\
\hline & & $(.077)$ & $(.073)$ & $(.069)$ & $(.065)$ & $(.060)$ \\
\hline & Post & .029 & .041 & .053 & .052 & .049 \\
\hline & & $(.032)$ & $(.032)$ & $(.033)$ & $(.032)$ & $(.032)$ \\
\hline & Post*Treat & -.024 & -.062 & $-.091^{*}$ & $-.108^{* *}$ & $-.096^{*}$ \\
\hline & & $(.076)$ & $(.059)$ & $(.053)$ & $(.052)$ & $(.050)$ \\
\hline & Subpop obs. & 411 & 515 & 592 & 652 & 710 \\
\hline & $\mathrm{T}$ in 2004 base & n empl & oyment & 1998 a & ed 2004 & \\
\hline & Treat & -.019 & .006 & .018 & .035 & .066 \\
\hline & & $(.085)$ & $(.082)$ & $(.079)$ & $(.073)$ & $(.066)$ \\
\hline & Post & .001 & .024 & .030 & .019 & .012 \\
\hline & & $(.039)$ & $(.039)$ & $(.039)$ & $(.038)$ & $(.038)$ \\
\hline & Post*Treat & -.088 & -.061 & $-.105^{*}$ & $-.127^{* *}$ & $-.119^{* *}$ \\
\hline & & $(.082)$ & $(.071)$ & $(.063)$ & $(.060)$ & $(.057)$ \\
\hline & Subpop obs. & 249 & 324 & 380 & 427 & 470 \\
\hline & Non-unionised, priv & sector wor & kplaces. & & & \\
\hline & Controls: Total emp & ment, age, & dummies & indt est, & multiprod, & nk shares, \\
\hline & geo market (reg/na & ), for com & $p, \cos t t$ & gets, In & Reg, Occ & hares. \\
\hline & Significance levels:* & $y_{0} * 5 \% *$ & $* 1 \%$ & & & \\
\hline & Weighted estimates & ndard erro & rs accoun & for con & lex design. & \\
\hline & Data from WERS & and 1998 . & & & & \\
\hline
\end{tabular}


Table 7: Estimates from a linear probability model for the probability of any fixed-term workers in the workplace.

\begin{tabular}{|c|c|c|c|c|c|}
\hline$(1$ & $(2)$ & $(3$ & \multicolumn{2}{|c|}{ (4) } & $(5)$ \\
\hline Max Empl for T: & 31 & 36 & \multicolumn{2}{|c|}{41} & 46 \\
\hline \multicolumn{6}{|c|}{$T$ in 2004 based on employment 2004} \\
\hline NonUnion & $\begin{array}{l}.075 \\
(.079)\end{array}$ & $\begin{array}{c}.077 \\
(.079)\end{array}$ & $\begin{array}{c}.084 \\
(.080)\end{array}$ & $\begin{array}{c}.081 \\
(.077)\end{array}$ & $\begin{array}{c}.085 \\
(.077)\end{array}$ \\
\hline Above21 & $\begin{array}{l}-.044 \\
(.105)\end{array}$ & $\begin{array}{l}-.038 \\
(.103)\end{array}$ & $\begin{array}{l}-.042 \\
(.098)\end{array}$ & $\begin{array}{l}-.011 \\
(.102)\end{array}$ & $\begin{array}{l}-.032 \\
(.096)\end{array}$ \\
\hline Post & $\begin{array}{l}-.025 \\
(.097)\end{array}$ & $\begin{array}{l}-.005 \\
(.096)\end{array}$ & $\begin{array}{l}-.008 \\
(.095)\end{array}$ & $\begin{array}{l}-.009 \\
(.093)\end{array}$ & $\begin{array}{c}.001 \\
(.092)\end{array}$ \\
\hline Above $21 *$ NonUnion & $\begin{array}{l}-.009 \\
(.111)\end{array}$ & $\begin{array}{c}.058 \\
(.105)\end{array}$ & $\begin{array}{c}.047 \\
(.096)\end{array}$ & $\begin{array}{l}-.008 \\
(.104)\end{array}$ & $\begin{array}{l}-.004 \\
(.099)\end{array}$ \\
\hline Post*Above21 & $\begin{array}{l}.140 \\
.162)\end{array}$ & $\begin{array}{c}.120 \\
(.144)\end{array}$ & $\begin{array}{c}.140 \\
(.134)\end{array}$ & $\begin{array}{c}.104 \\
(.140)\end{array}$ & $\begin{array}{c}.116 \\
(.132)\end{array}$ \\
\hline Post*NonUnion & $\begin{array}{l}-.089 \\
(.107)\end{array}$ & $\begin{array}{l}-.095 \\
(.105)\end{array}$ & $\begin{array}{l}-.079 \\
(.105)\end{array}$ & $\begin{array}{l}-.071 \\
(.102)\end{array}$ & $\begin{array}{l}-.077 \\
(.102)\end{array}$ \\
\hline Post*NonUnion*Above21 & $\begin{array}{l}-.047 \\
(.186)\end{array}$ & $\begin{array}{l}-.102 \\
(.162)\end{array}$ & $\begin{array}{l}-.117 \\
(.148)\end{array}$ & $\begin{array}{l}-.080 \\
(.153)\end{array}$ & $\begin{array}{l}-.086 \\
(.144)\end{array}$ \\
\hline Subpop obs. & 492 & 613 & 706 & 788 & 865 \\
\hline \multicolumn{6}{|c|}{ T in 2004 based on employment 1998 and 2004} \\
\hline NonUnion & $\begin{array}{l}.052 \\
(.084)\end{array}$ & $\begin{array}{c}.061 \\
(.082)\end{array}$ & $\begin{array}{c}.073 \\
(.082)\end{array}$ & $\begin{array}{c}.072 \\
(.079)\end{array}$ & $\begin{array}{c}.078 \\
(.079)\end{array}$ \\
\hline Above21 & $\begin{array}{l}-.079 \\
(.121)\end{array}$ & $\begin{array}{l}-.091 \\
(.119)\end{array}$ & $\begin{array}{l}-.066 \\
(.110)\end{array}$ & $\begin{array}{l}-.041 \\
(.109)\end{array}$ & $\begin{array}{l}-.043 \\
(.103)\end{array}$ \\
\hline Post & $\begin{array}{l}-.131 \\
(.115)\end{array}$ & $\begin{array}{l}-.089 \\
(.112)\end{array}$ & $\begin{array}{l}-.075 \\
(.109)\end{array}$ & $\begin{array}{l}-.090 \\
(.107)\end{array}$ & $\begin{array}{l}-.075 \\
(.106)\end{array}$ \\
\hline Above21*NonUnion & $\begin{array}{l}.017 \\
(.121)\end{array}$ & $\begin{array}{c}.082 \\
(.110)\end{array}$ & $\begin{array}{c}.061 \\
(.099)\end{array}$ & $\begin{array}{c}.005 \\
(.106)\end{array}$ & $\begin{array}{c}.006 \\
(.100)\end{array}$ \\
\hline Post*Above21 & $\begin{array}{l}.162 \\
(.306)\end{array}$ & $\begin{array}{l}.138 \\
(.191)\end{array}$ & $\begin{array}{c}.121 \\
(.169)\end{array}$ & $\begin{array}{c}.154 \\
(.162)\end{array}$ & $\begin{array}{c}.150 \\
(.155)\end{array}$ \\
\hline Post*NonUnion & $\begin{array}{l}-.008 \\
(.127)\end{array}$ & $\begin{array}{l}-.027 \\
(.125)\end{array}$ & $\begin{array}{l}-.034 \\
(.122)\end{array}$ & $\begin{array}{l}-.005 \\
(.120)\end{array}$ & $\begin{array}{l}-.015 \\
(.119)\end{array}$ \\
\hline Post*NonUnion*Above21 & $\begin{array}{l}-.174 \\
(.326)\end{array}$ & $\begin{array}{l}-.021 \\
(.225)\end{array}$ & $\begin{array}{l}-.032 \\
(.195)\end{array}$ & $\begin{array}{l}-.023 \\
(.184)\end{array}$ & $\begin{array}{l}-.043 \\
(.176)\end{array}$ \\
\hline Subpop obs. & 299 & 386 & 453 & 521 & 577 \\
\hline $\begin{array}{l}\text { a: Total employment, age } \\
\text { geo market (reg/nat/int) } \\
\text { Significance levels:* } 10 \% \\
\text { Weighted estimates, stan } \\
\text { Data from WERS } 2004 \text { a }\end{array}$ & $\begin{array}{l}\mathrm{umm} \\
\mathrm{r} \text { com } \\
5 \% \\
\text { d err }\end{array}$ & $\begin{array}{l}\text { ind } \\
\text { cost t } \\
1 \% \\
\text { accou }\end{array}$ & $\begin{array}{l}\text { ol, mı } \\
\text { ets. }\end{array}$ & $\overline{p r}, \mathrm{mk}$ & \\
\hline
\end{tabular}


Table 8: Estimates from a linear probability model for the probability of any agency workers in the workplace.

\begin{tabular}{|c|c|c|c|c|c|}
\hline \multicolumn{2}{|c|}{ (1) } & $\overline{(2)}$ & \multicolumn{2}{|c|}{$(4)$} & $(5)$ \\
\hline Max Empl for $\mathrm{T}$ : & 26 & 31 & 36 & 41 & 46 \\
\hline \multicolumn{6}{|c|}{$T$ in 2004 based on employment 2004} \\
\hline \multirow[t]{2}{*}{ NonUnion } & $-.153^{* *}$ & $-.151^{* *}$ & $-.140^{*}$ & $-.136^{*}$ & $-.132^{*}$ \\
\hline & $(.069)$ & $(.071)$ & $(.073)$ & $(.073)$ & $(.073)$ \\
\hline \multirow[t]{2}{*}{ Above21 } & -.100 & -.044 & -.068 & -.077 & -.072 \\
\hline & $(.092)$ & $(.093)$ & $(.091)$ & $(.089)$ & $(.086)$ \\
\hline \multirow[t]{2}{*}{ Post } & $-.157^{*}$ & $-.153^{*}$ & -.129 & -.135 & -.135 \\
\hline & $(.088)$ & $(.088)$ & $(.087)$ & $(.087)$ & $(.086)$ \\
\hline \multirow{2}{*}{ Above $21 *$ NonUnion } & .105 & .070 & .127 & $.145^{*}$ & $.147^{*}$ \\
\hline & $(.099)$ & $(.097)$ & $(.092)$ & $(.088)$ & $(.086)$ \\
\hline \multirow[t]{2}{*}{ Post*Above 21} & .125 & .075 & .072 & .098 & .130 \\
\hline & $(.139)$ & $(.126)$ & $(.115)$ & $(.108)$ & $(.107)$ \\
\hline \multirow[t]{2}{*}{ Post*NonUnion } & $.195^{* *}$ & $.203^{* *}$ & $.188^{* *}$ & $.193^{* *}$ & $.189^{* *}$ \\
\hline & $(.095)$ & $(.094)$ & $(.094)$ & $(.094)$ & $(.093)$ \\
\hline \multirow[t]{2}{*}{ Post*NonUnion*Above21 } & -.162 & -.152 & -.178 & $-.215^{*}$ & $-.236^{* *}$ \\
\hline & $(.159)$ & $(.141)$ & $(.129)$ & $(.122)$ & $(.119)$ \\
\hline Subpop obs. & 492 & 613 & 706 & 788 & 865 \\
\hline \multicolumn{6}{|c|}{$T$ in 2004 based on employment 1998 and 2004} \\
\hline \multirow[t]{2}{*}{ NonUnion } & $-.154^{* *}$ & $-.150 * *$ & $-.140^{*}$ & $-.133^{*}$ & $-.127^{*}$ \\
\hline & $(.069)$ & $(.071)$ & $(.075)$ & $(.074)$ & $(.074)$ \\
\hline \multirow[t]{2}{*}{ Above21 } & -.118 & -.080 & -.099 & -.092 & -.067 \\
\hline & $(.097)$ & $(.096)$ & $(.097)$ & $(.091)$ & $(.087)$ \\
\hline \multirow[t]{2}{*}{ Post } & -.176 & -.159 & -.123 & -.119 & -.112 \\
\hline & $(.127)$ & $(.126)$ & $(.120)$ & $(.119)$ & $(.117)$ \\
\hline \multirow[t]{2}{*}{ Above $21 *$ NonUnion } & .088 & .052 & .111 & .134 & .136 \\
\hline & $(.101)$ & $(.095)$ & $(.092)$ & $(.087)$ & $(.085)$ \\
\hline \multirow[t]{2}{*}{ Post*Above21 } & .098 & .107 & .084 & .047 & .035 \\
\hline & $(.145)$ & $(.164)$ & $(.155)$ & $(.138)$ & $(.131)$ \\
\hline \multirow[t]{2}{*}{ Post*NonUnion } & .187 & .196 & .160 & .148 & .135 \\
\hline & $(.133)$ & $(.132)$ & $(.126)$ & $(.124)$ & $(.123)$ \\
\hline \multirow[t]{2}{*}{ Post*NonUnion*Above21 } & -.209 & -.201 & -.220 & -.199 & -.175 \\
\hline & $(.158)$ & $(.181)$ & $(.168)$ & $(.153)$ & $(.145)$ \\
\hline Subpop obs. & 299 & 386 & 453 & 521 & 577 \\
\hline \multicolumn{6}{|c|}{$\begin{array}{l}\text { a: Total employment, age, dummies: ind establ, multipr ,mk shares, } \\
\text { geo market (reg/nat/int), for comp, cost targets. } \\
\text { Significance levels: }{ }^{*} 10 \% * * 5 \% * * * 1 \% \\
\text { Weighted estimates, standard errors account for complex design. } \\
\text { Data from WERS } 2004 \text { and } 1998 \text {. }\end{array}$} \\
\hline
\end{tabular}




\section{References}

ACAS (2001). Annual report 2000/2001. Annual report, Advisory Conciliation and Arbitration Service.

ACAS (2003). Annual report 2002/2003. Annual report, Advisory Conciliation and Arbitration Service.

ACAS (2004). Annual report 2003/2004. Annual report, Advisory Conciliation and Arbitration Service.

Angrist, J. D. and J.-S. Pischke (2009). Mostly harmless econometrics. Princeton University Press.

Arulampalam, W. and A. L. Booth (1998). Training and labour market flexibility: Is there a trade-off? British Journal of Industrial Relations 36, 521-536(16).

Arulampalam, W., A. L. Booth, and M. L. Bryan (2004). Training in Europe. Journal of the European Economic Association 2(2-3), 346-360.

Autor, D. (Ed.) (2009). Studies of labor market intermediation. The University of Chicago Press.

Autor, D. H. (2003, January). Outsourcing at will: The contribution of unjust dismissal doctrine to the growth of employment outsourcing. Journal of Labor Economics 21(1), $1-42$.

Belfield, C. R. and J. S. Heywood (2001, December). Unionization and the pattern of nonunion wages: Evidence for the UK. Oxford Bulletin of Economics and Statistics 63(5), $577-98$.

Blanden, J., S. Machin, and J. Reenen (2006). Have unions turned the corner? New evidence on recent trends in union recognition in UK firms. British Journal of Industrial Relations 44(2), 169-190.

Blundell, R. and M. C. Dias (2009). Alternative approaches to evaluation in empirical microeconomics. Journal of Human Resources 44(3), p565-640.

Booth, A. L. (1995). The Economics of Trade Union. Cambridge: Cambridge University Press.

Booth, A. L., M. Francesconi, and J. Frank (2002, June). Temporary jobs: Stepping stones or dead ends? Economic Journal 112(480), F189-F213.

Broschak, J. and A. Davis-Blake (2006, APR). Mixing standard work and nonstandard deals: The consequences of heterogeneity in employment arrangements. Academy of Management Journal $49(2), 371-393$.

Brunello, G., P. Garibaldi, and E. Wasmer (2007). Education and Training in Europe. Oxford: Oxford University Press. 
Bryson, A. (2007). Temporary agency workers and workplace performance in the private sector. Manpower Human Resources Lab Discussion Paper, London School of Economics 3.

Böheim, R. and M. Zweimüller (2009, October). The employment of temporary agency workers in the uk: With or against the trade unions? IZA Discussion Papers 4492, Institute for the Study of Labor (IZA).

Corneo, G. and C. Lucifora (1997). Wage formation under union threat effects: Theory and empirical evidence. Labour Economics 4(3), 265-292.

DiNardo, J. and D. S. Lee (2004, November). Economic impacts of new unionization on private sector employers: 1984-2001. The Quarterly Journal of Economics 119(4), 13831441.

DTI (2003). Review of the employment relations act 1999. Review paper, Department of Trade and Industry.

DTI (2005). Trade union membership 2004. Annual report, Department of Trade and Industry.

Dundon, T. (2002). Employer opposition and union avoidance in the UK. Industrial Relations Journal 33(3), 234-245.

Eurofound (2010). Trade Union strategies to recruit new groups of workers. Occasional paper, Eurofound.

Farber, H. S. (2005). Nonunion wage rates and the threat of unionization. Industrial and Labor Relations Review 58(3), 335-352.

Freeman, R. and J. Medoff (1981). The impact of the percentage organise on union and non-union wages. Review of Economics and Statistics 63(4), 561-572.

Gramm, C. L. and J. F. Schnell (2001). The use of flexible staffing arrangements in core production jobs. Industrial and Labor Relations Review 54 (2), 245-258.

Hamermesh, D. S. (2000). The craft of labormetrics. Industrial Labor Relations Review 53(3), $363-380$.

Heery, E. (2004). The trade union response to agency labour in Britain. Industrial Relations Journal 35(5), 434-450.

Houseman, S. N. (2001). Why employers use flexible staffing arrangements: Evidence from an establishment survey. Industrial and Labor Relations Review 55(1), 149-170.

Imbens, G. M. and J. M. Wooldridge (2008). Recent developments in the econometrics of program evaluation. NBER Working Papers 14251, National Bureau of Economic Research, Inc.

Kahn, L. M. (2007, 06). The impact of employment protection mandates on demographic temporary employment patterns: International microeconomic evidence. Economic Journal 117(521), 333-356. 
Kersley, B., C. Alpin, J. Forth, A. Bryson, H. Bewley, G. Dix, and S. Oxenbridge (2005). First Findings from the 2004 Workplace Employment Relations Survey. Technical report.

Kraimer, M. L., S. J. Wayne, R. C. Liden, and R. T. Sparrowe (2005). The role of job security in understanding the relationship between employees' perceptions of temporary workers and employees' performance. Journal of Applied Psychology 90(2), 389 - 398.

Kugler, A., J. F. Jimeno, and V. Hernanz (2005). Employment consequences of restrictive permanent contracts: Evidence from Spanish labor market reforms. Technical report.

Kugler, A. and G. Pica (2008). Effects of employment protection on worker and job flows: Evidence from the 1990 Italian reform. Labour Economics 15(1), 78-95.

Lee, M.-J. (2005). Micro-econometrics for policy, program and treatment effects (1st Edition ed.). Oxford University Press.

Lewis, G. H. (1963). Unionisim and relative wages in the United States. University of Chicago Press.

Lewis, G. H. (1986). Union relative wage effects: a survey. University of Chicago Press.

Neumark, D. and M. L. Wachter (1995, October). Union effects on nonunion wages: Evidence from panel data on industries and cities. Industrial and Labor Relations Review 49(1), $20-38$.

OECD (2002). Employment Outlook. Paris: OECD.

Oxenbridge, S., W. Brown, S. Deakin, and C. Pratten (2003). Initial responses to the statutory recognition provisions of the employment relations act 1999. British Journal of Industrial Relations 41(2), 315-334.

Pearce, J. L. (1993). Toward an organizational behavior of contract laborers: Their psychological involvement and effects on employee co-workers. The Academy of Management Journal 36(5), 1082-1096.

Rosen, S. (1969, April). Trade union power, threat effects and the extent of organization. Review of Economic Studies 36(106), 185-96.

Salvatori, A. (2009, November). What do unions do to temporary employment? IZA Discussion Papers 4554, Institute for the Study of Labor (IZA).

Salvatori, A. (2010). Labour contract regulations and workers' wellbeing: international longitudinal evidence. Labour Economics 17(4), 667-678.

Verma, A. (2003, August). What do unions do to the workplace? Union effects on management and HRM policies. Journal of Labor Research 26(3), 415-449.

Wood, S. and J. Goddard (1999). The statutory union recognition procedure in the Employment Relations Bill: a comparative analysis. British Journal of Industrial Relations 37(2), 203-245.

Wooldridge, J. (2002). Econometric analysis of cross section and panel data. The MIT Press. 